\title{
The Internet and Increased Citizen Participation in Government
}

\author{
Michael E. Milakovich, Ph.D. \\ Department of Political Science, University of Miami, Coral Gables, Florida USA, Email: milov@miami.edu
}

\begin{abstract}
What roles do communication systems, information technologies and the internet play in fostering citizen participation and influencing the electoral and administrative decisions of government? The internet is simultaneously a world-wide broadcasting network, a mechanism for information dissemination, and a medium for collaboration and interaction between individuals and their computers without regard for geographic boundaries or time zones. This article describes the origins of participatory democracy, discusses how modern concepts of democracy link to citizen participation, and describes the ways that newly-created spaces on the internet referred to as "polispheres" are being used by political activists and candidates to facilitate wider collaboration and citizen participation. The following questions are addressed: What role does the internet play in fostering and aiding citizen participation in government? Does increased involvement lead to greater trust and confidence in government? What role did the internet play in apparently reversing downward trends in citizen apathy and drawing 8 million new voters to the United States 2008 presidential election? The article suggests that information technology facilitates broader citizen participation and identifies the challenges facing governments in adopting internet-based ICT strategies.
\end{abstract}

Keywords: democracy, information technology, mass media, internet, citizen participation, government, information and communication technology (ICTs)

Acknowledgement: Thanks to Thomas Holmstrom Frandzen, Nele Leosk, David Newman, Matt Poelmans, and Alexander Prosser for their help in reviewing and earlier version of this paper presented at EDEM 2009-Conference on Electronic Democracy in Vienna.

- here have been numerous theories of democracy dating from the founding of the city-state in ancient Athens, Greece. The philosophical and theoretical origins of democracy can be traced as far back as Plato's Republic in ancient Athens. Platonic concepts of freedom of assembly, equal representation, freedom of speech and electoral participation through voting formed the foundations upon which advanced post-monarchial industrial democracies were founded. Although Athenian Democracy was an 'elitist' form of citizenship with representatives who met weekly to decide legislative issues after consulting with citizens, concepts of citizen participation and representative democracy have evolved with democratic principles as societies have become more complex.

Democratic principles are embedded in the constitutions of many representative democracies and include, at a minimum:

1. Freedom of the assembly, speech, religion, press and other media outlets to criticize the government in power;

2. Other "expressed" freedoms from government action such as those embodied in the Bill of Rights, the first ten amendment s to the U.S. Constitution;

3. Periodic free and open elections among competing political groups based on principles of equal representation (e.g. one person = one vote);

4. An independent judicial branch with the authority to review the actions of the executive and legislative branches of government; 
5. Written procedures for limiting the powers of government, resolving conflicts and protecting minority rights.

Participatory democracy implies a more activist citizenry directly involved in the processes of governmental decision making. Citizen participation in public decision making is encouraged and expected.

Compared with the Platonic ideal of individual citizen action and participation, the internet is a new phenomenon that facilitates mass communication in technologically-equipped societies. Unlike other mass media, the internet facilitates new forms of two-way communication and political participation, encourages interaction among citizens and public officials and provides a rich forum for discussion of contentious political issues. According to one observer, e-government has the potential to become "an institution that helps to ensure reasoned reflection about political issues and active participation in deliberative democracy by citizens and by members of the government" (Jaeger, 2005, p. 703). Moreover, ICTs increasingly affect the cultural, economic, social and political lives of millions of citizens throughout the world. National, state and local governments are establishing a strong presence on the World Wide Web, both for disseminating information to the public and for receiving feedback from the public. Inevitably, breakthroughs similar to the direct citizen-candidate communication which characterized President Obama's 2008 high-tech campaign will be made in the newly emerging polisphere, that portion of internet space devoted to political activities such as blogging and partisan discussion to enhance citizen participation.

\section{What is citizen participation how is it defined?}

Citizen participation can be defined in many ways. Traditionally, it concerns voluntary or coerced participation in local, state and national issues that involve governmental decision-making. The term "coercion" does not imply the use of force or violence. Rather, it is used in the same sense that Theodore J. Lowi describes "forced compliance" with government rules and regulations (Lowi, 1964). (One example of this option is the imposition of small civil fines for failure to vote used in many democratic countries (not the United States) to "coerce" electoral participation.) Citizen participation implies a readiness on the part of both citizens and government institutions to accept certain pre-defined civic responsibilities and roles. It also means that each contribution is accepted, valued and possibly used in decision making. The inclusion of citizen representatives as co-equal partners in decision-making processes contributes to successful citizen participation. In some form, citizen participation has played a significant role in democratic forms of government since the founding of organized societies.

The ideology of citizen participation has firm roots in democratic political values, especially relating to the concept of participatory democracy. In the United States, the push for greater citizen participation in government decision making was reborn in the 1960s out of related movements for civil rights, "black liberation," and decentralization of urban government structures. It originated in demands by minorities for a larger voice in determining policies and programs directly affecting them. The urban poor, at least during the 1960s, concentrated on organizing themselves and confronting those in power with demands for change. Their participation was formally incorporated in both the planning and implementation of federal Model Cities and community-action programs and in other programs since then.

\subsection{Forms and Practices of Citizen Participation}

The forms and practices of citizen participation are numerous, ranging from advising agencies to attending hearings to actual decision making. In addition to making statements at meetings held by administrative agencies, individuals may take part in budget and other legislative hearings, and in initiatives and referenda; serve on advisory committees; participate in focus groups and respond to citizen surveys; and, in some cases, sit on governing boards of operating activities funded by government entities. Also, in the delivery of human services, individuals act as coproducers of the services by their involvement in program operations (this refers to services such as unemployment 
compensation, job assistance, garbage collection, and education). Viewing the citizen as coproducer is a different but highly relevant conception of participation that should not be overlooked. The same kind of active role is an essential ingredient in the more contemporary attempts to provide improved customer service and empower local communities to act in their own interests. With passage to health care reform, more U.S. citizens will be forced to make choices regarding medical insurance plans.

Specific purposes of participation can include some or all of the following: (1) providing information to citizens; (2) receiving information from or about citizens; (3) improving public decision processes, programs, projects, and services; (4) enhancing public acceptance of governmental activities; (5) altering patterns of political power and allocations of public resources; (6) protecting individual and minority-group rights and interests; and (7) delaying or avoiding difficult public-policy decisions. (Redistributing power and resources and protecting minority interests were central to the demands of urban nonwhites in the 1960s.) Although some of these purposes are mutually incompatible, all are directed generally toward reducing citizen alienation from government. This is a form of grassroots involvement that can also be used to hold public officials accountable. All of these purposes are enhanced by internet-based information and communication technologies (ICTs).

\subsection{Empowerment and Diversity}

The empowering capability of ICTs is centered on their ability to permit previously marginalized individuals and groups - who would otherwise be silent and invisible - to be heard and seen. By doing so, ICTs reveal the diversity in society, a range of opinion that has always existed, but was previously without voice in public decision making. This, in part, is due to the fact that ICTs facilitate the dispersal of power away from centralized governments with the result that rational, administrative institutions are being challenged as a sole means of political and social control. In what appears to be a worldwide phenomenon, bureaucratic institutions are losing their monopoly over key sources of information and the capacity for surveillance, permitting alternative voices in civil society to emerge.

In many ways, ICTs, particularly the internet, have become highly advantageous to citizen activists, non-governmental organizations, and new social movements that seek to challenge and occupy new public spaces in which formerly disenfranchised citizens can participate. These new public spaces also pose challenges to the contribution of the leading theories of the public sphere, or the polisphere. The internet facilitates the proliferation of an unlimited number of alternative public spaces, or counter-public spheres, as well as the growth of a common public sphere of discussion and deliberation. The continuously expanding internet promotes oppositional "blogispheres" complete with sophisticated systems of networking and communication. These polispheres express a much wider variety of opinions and options than possessed by earlier nineteenth and twentieth century counter public organizational media which offered a vast amount of information in the form of documents, reports, critiques, press releases, alternative magazines and newspapers, audio, video, list serves, chat groups and references to other relevant sites. For those who feel excluded from the dominant public media, the internet—with its estimated 30 billion websites and 112 million weblogs or "blogs"-offers rapid access to an alternative world of expression, networking and organizing. One of the effects of this new form of communication is that it could intensify the postmodern challenge to traditional authority structures, as has been seen in developing countries such as China, Cuba, Iran, and Mexico.

\subsection{Reflecting Ideological Differences}

Ideological differences about citizen participation and debates over its place in governing are related conceptually to the continuing debate in American and European politics over centralization and decentralization of administrative authority. Particularly as practiced in the federal system during the past quarter-century, citizen participation represents an application of the decentralist 
principle, which assumes value and purpose in delegating decision-making authority to broader numbers of affected persons and groups. Decentralization as a mode of operation clearly permits wider participation; it gives greater assurance that the existing spectrum of opinion will receive a hearing; and it lends more legitimacy to both the process and the outcomes of decision making. Because federalism itself was designed as a bulwark against intrusive centralization, the concept of decentralization obviously has a place in operations under a federal system. Citizen participation, fostered by many national programs, has been a key mechanism used to promote decentralization of operating responsibility.

The Information Age is bringing more demands for accountability and transparency from a greater number of sources. As greater numbers of avenues of inquiry emerge, citizens seek more information about many activities in society. In the years to come, the public will expect accurate information, from both private and public organizations. The demand for increasing amounts of information is being driven by the internet where there is now so much discourse, exchange of information and millions of weblogs or "blogs". The internet is an open network, which is contributing to the development of open information environments. This idea is spreading into society as a whole, resulting in expectation of more assurances of accountability from all public and private sector organizations.

The concept of citizen participation has been applied in different ways to varying problems. Community control focused on neighborhood management of schools and delivery of other essential urban services, principally in nonwhite ghetto areas of major American cities. President Obama began his career following graduation from Harvard Law School as a community organizer on the South Side of Chicago. In other places, neighborhood and citizen-action organizations sprang up for the purpose of "preserving neighborhood character" and sometimes redevelopment of physical structures in the neighborhood. For example, there have been concerted efforts to prevent construction of interstate highway projects that would cut through, or perhaps level, parts of established urban neighborhoods; cattle ranchers in western states joining forces with Native Americans and antinuclear groups to oppose uranium mining by energy conglomerates; citizen groups protest toxic-waste disposal; and residential associations have tried to attract (or repel) commercial enterprises such as Home Depot, McDonald's or Wal-Mart. Organized antitax movements, such as the Ruby Ridge, Idaho and Waco, Texas, incidents in August, 1992 and April, 1993, and the bombing of the Alfred R. Murrah Federal Building in Oklahoma City in April, 1995, illustrate the extremes to which some groups have gone to protest actions of government agencies (Milakovich \& Gordon, 2009).

Citizen participation also has been incorporated into formal mechanisms for decision making. At the national level, for example, public participation in regulatory proceedings has been increasing, although with considerable variation in regulators' responses and opportunities provided to citizen groups, such as consumer and environmental organizations. Agencies and commissions undoubtedly have legal discretionary authority to decide just how much public participation (if any) to permit and, particularly, whether and how to finance participation by those with limited resources. Nonetheless, there has been considerable frustration on the part of public interest groups (PIGs), which have been slow to gain access to regulatory proceedings. And, at the local level, participation is now more regularized, especially in building code and zoning enforcement, environmental protection, and planning and design of urban communities.

In modern high-tech democratic societies with multiple competing communications systems, it is often difficult to encourage citizens-especially those with greater access to resources and varying political ideologies and objectives-to band together to discuss and decide complex political issues. The New England town meeting, an early American tradition that combined citizen participation with representative democracy, is now all but a quaint memory. The mass media, especially television, and more recently the internet, have substituted for direct participation and assumed greater roles in articulating and defining public opinion upon which citizen attitudes are based. The advantage of the internet as a medium for citizen participation has been touted for various purposes only for a relatively short period of time-prior to 2008 there was no 
comprehensive strategy to successfully apply information technology to electoral processes (Heeks, 1999). Barack Obama's 2008 successful run for the presidency was the first American national political campaign to successfully apply new information technologies to garner political contributions and generate new voters. Whether or not this participatory strategy can be converted to improving the administration of public programs or initiating new policy initiatives remains to be seen.

\section{How Obama Won}

The use of the internet for political communication accelerated during the 2008 presidential campaign partly due to President Obama's tech-savvy campaign advisors; its widespread use may have significantly impacted the results of the 2008 presidential elections (Hill, 2009; Hendricks \& Denton, 2010). This type of e-campaigning uses ICTs as a means to mobilize volunteers, raise funds, disseminate information and otherwise pursue the various functions of running for elective office (Garson, 2006). The approach reinforces dual patterns of communication, social interaction and decision making: that is, less centralized decision making processes (due to the limited ability of leaders to comprehend fully all the specialties of the people in their organizations) and broader participation due to the accessibility and low cost of cellular phones and internet connectivity. This pattern of information and communication exchange is more likely to result in more informed decisions from the use of various knowledge management tools that generally characterize newer, networked, non-hierarchical systems of modern technology-driven organizations (Wimmer, 2004).

President Barack Obama was the first candidate for national office to successfully merge information and communication technologies (ICTs) and employ the internet and social networking to generate new voters as well as garner increased campaign contributions. In a dramatic reversal of traditional fund-raising capabilities, the Democrats out-earned the Republicans by nearly a 2 to 1 margin during the 2008 Presidential campaign. By the end of the campaign, one of his websites, myBarackObama.com, chalked up some 1.5 million accounts. And Obama raised a recordbreaking $\$ 600$ million in contributions from more than three million people, many of whom donated directly through the web (http://www.wired.com/threatlevel/2008/11/propelled-by-in/). In addition, Obama recruited nearly 14 million online supporters (many of them first time voters), and communicated directly with them by email and cell phones-as no previous candidate had- and via social networking websites such as Facebook, MySpace, YouTube, and Twitter. The Obama campaign constantly placed advertisements in the side columns of the Facebook website, $52 \%$ of whose users are between the ages of 18-25. There were pictures of either him individually, or of him with his entire family in a pleasant family photo. The caption usually read either: "Register to Vote" or "Election Day is November $4^{\text {th }}$ " or "Vote Early." He also had a "Support Obama" Facebook group which would periodically send messages to members who had joined that had information about polling sites, early voting information, and updates on his campaign. (For an article on the demographics of the site, see: http://www.insidefacebook.com/2008/09/18/latest-data-on-usfacebook-age-and-gender-demographics/). During the 2008 presidential campaign, candidate Obama even announced his vice presidential selection at 3:00 AM via an internet and cell phone message to supporters. His ubiquitous Blackberry has become a symbol of his administration's high-tech communication style. How did Obama use ICTs to recruit new voters and generate millions of dollars in campaign contributions?

Obama's victory in the Electoral College was impressive, but not a radical departure from past presidential campaigns (Todd \& Gawiser, 2009). First, his campaign obviously benefitted from antiwar sentiment, the Bush administration's inept handling of the economy and the subprime "mortgage meltdown" in the months immediately before the election. Second, the massive federal debt created by the wars in Iraq and Afghanistan and the collapse of financial markets and property values beginning in 2007, mobilized millions of anti-Republican voters, especially Independents, who turned out in large numbers for Obama and other Democrats. Third, his opponent, Sen. John McCain (Republican from Arizona), admitted he had little understanding of either computers or the interconnections being created in a modern technology-driven political campaign. And last, 
Obama's use of electronic media struck a responsive chord with millions of younger, tech-savvy new voters who grew up with ICTs and were motivated to participate by direct and fast contact, collaboration and information sharing with the candidate.

Clearly, the internet played a significant role in promoting additional citizen participation in government. The causal linkages between fund raising, party identification, social networking and voter turnouts are difficult to establish with precision: they are currently being explored in more depth and detail by political scientists. The ultimate impact that the Obama campaign may have had on the (online and offline) polispheres in the United States and elsewhere will ultimately be determined by his administration's success in achieving policy changes, especially in the areas of environmental regulation and universal healthcare coverage.

As the first U.S. president to successfully employ ICTs for electoral success, Barack Obama is now attempting to convert these new information and communication technologies to further his administration's ambitious public policy goals. The Obama administration is applying this strategy as a 'blueprint' for communicating directly with citizens and further reforming administrative procedures in a wide variety of policy areas. For instance, one of his first actions in the spring, 2009 was to upgrade technology management positions to directly report to the White House. In addition, many of Obama's supporters continue to work toward his administration's policy agenda in groups such as Organizing for America (http://my.barackobama.com/page/community/post/stateupdates/gGxFi8) lead by former Virginia Governor and Democratic National Committee Chair Tim Keane. Despite such intentions, the public bureaucracy, the so-called 'action' side of government, often lacks the capacity, competence and the motivation to breakthrough ingrained administrative processes and initiate innovative reforms to remove barriers to admission, collaboration and participation. According to Jonathan Bruel, Executive Director of the IBM Center for the Business of Government, "The [federal] workforce and the tools it is using are not up to the challenge, [creating] a disconnect between the tech-savvy Obama administratio and the federal bureaucracy, which hasn't fully embraced those technologies." (Carlstrom, 2008). This potential divide, in addition to the constitutional separation of federal, state and local governments, as well as remnants of the Bush administration occupying key high-level policymaking positions, suggests that there may be more resistance to change than first imagined. Moreover, any new president's appointment powers are limited to a few thousand high-level senior cabinet-level jobs out of approximately five million federal civilian and military employees, leaving many appointees from previous administrations in positions to influence the implementation of key policy decisions. Thus, even if skilled specialists are available in sufficient numbers to facilitate the use of technology to reform bureaucracy, they may not share the same policy goals as the current administration.

\section{Citizen Participation under President Obama}

Citizen participation has been a key phrase in Obama's technological policy vernacular since the start of his campaign. In his campaign literature, Obama went even further and pledged to use the most current technological tools available to make government less beholden to special interest groups and lobbyists and to promote more citizen participation in government decision-making. Part of this approach included the development of the Technology, Innovation and Government Reform (TIGR) Working Group, a team of more than 30 tech industry professionals set to "create a 21st century government that is more open and effective; leverages technology to grow the economy, create jobs, and solve our country's most pressing problems; respects the integrity of and renews our commitment to science; and catalyzes active citizenship and partnerships in shared governance with civil society institutions." This group is broken into four teams: Innovation and Government, Innovation and National Priorities, Innovation and Sciences, and Innovation and Civil Society. The focus of the Policy Working Groups has been to develop the priority policy proposals and plans from the Obama Campaign for action during the Obama-Biden Administration. The Policy Working Groups will focus on the following areas: Economy, Education, Energy \& Environment, Health Care, Immigration, National Security, and Technology Innovation and Reform. 
Citizen participation in the political process is considered highly important to foster greater government accountability, transparency and responsiveness. Tools provided by information technologies can be used in the development of a more participatory democracy. This direct participation in political activities is called e-democracy. This concept is generally considered wider than e-government because of the implication in the way citizens relate to governments and to each other. Its objective, according to the United Nations Education, Scientific, and Cultural Organization (UNESCO), is to "strengthen public trust in government and to improve relations between the government and its citizens." Derived from e-democracy are specific types of applications such as e-voting, e-activism and e-participation. E-voting refers to the use of electronic means to provide citizens access to implement voting or polling process. E-participation refers to the use of electronic means to encourage public participation in governmental decision-making or agency rule making. E-activism refers to the use of electronic means to mobilize volunteers, raise funds, disseminate information and otherwise pursue the various functions of interest groups that seek to influence public policy (Garson, 2006, p. 61).

According to democratic theories, efforts to increase citizen participation result in better governmental decisions that involve larger numbers of citizens and are, therefore, more acceptable and legitimate to the majority of people. Better government decisions, by definition, are more beneficial to greater numbers of "average" citizens. Citizen participation provides a source of special insight, information, knowledge, and experience, which contributes to the soundness of government solutions to public problems. Active involvement in public affairs and in decisionmaking processes also serves to check and balance political activities, thereby increasing transparency and reducing the likelihood of public officials making self-serving decisions. Citizen input can legitimize a program, its purposes, implementation and leadership. Unsupported leaders often become discouraged and drop activities that are potentially beneficial to average citizens, but difficult to implement in contentious political environments. Voluntary participation can also reduce the cost of paid personnel needed to carry out many of the duties associated with community actions as extensions of governmental policy.

\section{Conclusion and Future Challenges}

What may be predicted about the impact of ICTs on participation of citizens in governance based on recent U.S. elections? Information and communication technologies on the internet can contribute as follows: better inform citizens about public issues and associated law making; facilitate debate (e.g. citizens can be in a better position to intervene by approaching their MP before a bill comes to the vote). Improving knowledge about candidates for parliaments and other public jobs, e.g. revealing their qualifications for office and political knowledge, their previous performance on election promises, campaign finance, which interest groups they support (e.g. business, religion, "worthy causes" such as natural environment or political party). Information prepares voters to cast their vote in a more informed and critical way. The ease of information provided by the internet and creation of new polispheres enables more citizens during and between elections to join in a public debate more easily, to monitor election promises, to intervene by writing to newspapers, or even to start campaigns aimed at influencing public opinion and parliamentary decisions. This would allow members of political parties to better judge the performance of their own delegates and candidates for public office. Encouraging and helping to empower citizens to be pro-active. Forms of expression may further consist of lobbying MPs, public officials and commercial enterprises; informing and educating others, publishing on the WWW; moral appeals; protest and social movements, "non-governmental" organizing; starting referenda or citizens' lawmaking; promoting the renewal of democracy itself. Public organizations will be pressured to designate a chief information officer. This person will make sure that "information planning and policy formulation" are carried out effectively by the administration in power (Dearstyne, 2001). One of President Obama's first official acts was to make such an appointment.

The ease of communication and access to information now and in the near future has led some observers to predict that a new public arena or "agora" will emerge to aid collective decision- 
making. Some developments during the coming few decades may be: closer guidance of MPs and governments by public will, especially in the legislative periods between elections to achieve a political party guided by constituents. Direct decision-making by citizens on a greater number of issues may be an illusory promise of e-government. It does not seem that many of the candidates for the EU Parliament have followed Obama's approach to campaigning. There have been some weak attempt for the European Commission to stimulate electoral participation, but voter turnouts have not increased, especially among the youngest Europeans. Gradual transformation of representative democracy into a process with more deliberation and more involvement of citizens will take time. Electronic voting to select candidates in elections and definitive votes on laws and public issues, with direct decision-making by constituents on some issues, remain major challenges for both citizens and governments (Robbins, Simonsen, \& Feldman, 2008).

Challenges to Citizens: Presenting the potential benefits of improved citizen participation may be regarded by some as idealistic, even unrealistic. For others it is a threat to their economic and political positions. Critics of direct democracy cite cases where citizens have acquired increased rights to legislate. In exercising their new democratic rights the majority may be highly selfish, acting to reduce personal taxation or to avoid any disturbance of own comfort (e.g. refusing to accept any personal or local environmental risks and so displacing these onto other citizens, the NIMBY "not in my backyard" philosophy). Other critics become even more alarmed, fearing a "dictatorship" of the majority, in modern terms projected as "an electronic mob".

Challenges to Government: To increase the number and security of inter- and intracommunication channels within federal, state and local government structures. Clear information strategies on issues such as goals, means/modes, time-space, evaluation, etc. need to be put in place for effective communication and the development of citizen-government partnerships. Future political support for effective information management systems linking citizen to government can not be assumed. As the use of the internet for two-way political communication increases, and the degree of participation improves, the incorporation and synthesis of large volumes of email messages and opinions received online may become increasingly difficult. The challenge for public managers and policy makers is to analyze and interpret the data and present it to citizens and political decision-makers in a comprehensible format.

\section{References}

Carlstrom, G. (2008). Obama's Bold Vision for E-Gov. Federal Times, November 18, 2008.

Dearstyne, B. (2001). E-Business, E-Government \& Information Proficiency. Information Management Journal, October 24 , 2001, 16-24

Garson, D. (2006). Public Information Technology and E-Governance: Managing the Virtual State. Sudbury, MA: Jones and Bartlett.

Heeks, R. (ed.) (1999). Reinventing Government in the Information Age - International Practice in IT-enabled Public Sector Reform. London: Routledge.

Hendricks J. \& Denton, R. (2010). Communicator-in-Chief: How Barack Obama Used New Media Technology to Win the White House. New York: Lexington Books.

Hill, S. (2009). The World Wide Webbed: The Obama Campaign's Masterful Use of the Internet. New America Foundation, Social Europe Journal. Retrieved July 2, 2009 from http://www.newamerica.net/publications/articles/2009/world wide webbed 12862

Jaeger, P. (2005). Deliberative Democracy and the Conceptual Foundations of Electronic Government. Government Information Quarterly, 22 (4), 702-719.

Lowi, T. (1964). American Business, Case Studies, and Political Theory. World Politics 16, 677-715.

Milakovich, M. \& Gordon, G. (2009). Public Administration in America (10th Ed.) Belmont, California: Wadsworth. 
Robbins, M., Simonsen, B. \& Feldman, B. (2008). Citizens and Resource Allocation: Improving Decision Making with Interactive Web-Based Citizen Participation. Public Administration Review, 68 (3), May-June, 564-575

Todd, C. \& Gawiser, S. (2009). How Obama Won: A State-By-State Guide to the Historic 2008 Presidential Election. New York: Vintage Books.

Wimmer, M. (Ed.) (2004). Knowledge Management in Electronic Government. Berlin: Springer.

\section{About the Author}

Michael E. Milakovich

Michael E. Milakovich (Ph.D. Indiana; B.A. UC-Santa Barbara) is a professor of political science and public administration at the University of Miami, Coral Gables, Florida. He has served as MPA Director, University of North Carolina-Greensboro, and Project Director for the University of Miami Institute for Quality in Manufacturing and Service, and is a Life Member of the American Society for Public Administration. His areas of specialization are: public management and productivity improvement, business-government relations, administration of justice, and healthcare management. He has authored or co-authored 14 books or monographs and published numerous articles, chapters, and reviews in referred journals such as the International Public Management Review, Public Performance and Management Review, American Review of Public Administration, American Political Science Review, Crime and Delinquency, Health Care Management REVIEW, Justice System Journal, National Productivity Review, National Civic Review, Quality Assurance and Utilization Review, and The Journal of Health and Human Resource Administration. His books include Public Administration in America 5th-10th Ed. w/ G. Gordon (Wadsworth/St. Martins Press, 1995-2009), Improving Service Quality in the Global Economy (Auerbach Press, 2006), Florida State and Local Government (Prentice-Hall, 1993), and U.S vs. Crime in the Streets w/T\&T Cronin (Indiana University Press, 1981), and Performance Management in Business and Government (in process). He is a Life Member of the American Society for Public Administration; serves as an expert witness in State and Federal courts; advises numerous public, private, non-profit and international organizations on policy analysis and quality improvement strategies; and is a member of several editorial boards. He has conducted global interdisciplinary research, consulted, presented papers and lectured with numerous businesses, governments, and health care organizations in the United States as well as in Austria, the Bahamas, Czech Republic, Denmark, Egypt, England, Hungary, Germany, Japan, Martinique, Turkey, and Venezuela. 